\title{
INVESTIGATION OF THE OPTIMAL TECHNOLOGY FOR COPPER LEACHING FROM OLD FLOTATION TAILINGS OF THE COPPER MINE BOR (SERBIA)
}

\author{
Vesna Conić ${ }^{1 *}$, Srđan Stanković ${ }^{2}$, Branislav Marković3 ${ }^{3}$, Dragana Božićl, \\ Jovica Stojanović, Miroslav Sokic ${ }^{3}$ \\ ${ }^{I}$ Mining and Metallurgy Institute, Zeleni Bulevar 35, 19210 Bor, Serbia \\ ${ }^{2}$ Federal Institute for Geosciences and Natural Resources, Stilleweg 2, \\ 30655 Hannover, Germany \\ ${ }^{3}$ Institute for Technology of Nuclear and Other Mineral Raw Materials, \\ Franchet d'Esperey Boulevard 86, 11000 Belgrade, Serbia
}

Received 10.06.2020

Accepted 08.07.2020

\begin{abstract}
This work aimed to investigate optimal leaching technology for copper extraction from old flotation tailings of the Copper Mine Bor. The leaching degree of copper after leaching with sulphuric acid at $80{ }^{\circ} \mathrm{C}$ was $50 \%$, the maximal leaching degree was achieved after 30 minutes. Then, old flotation tailings were leached with adapted moderately thermophilic acidophilic bacteria in a bioreactor at $40{ }^{\circ} \mathrm{C}$. Maximal leaching degree of $84 \%$ was achieved after nine days of the experiment. The third leaching experiment was conducted with biogenic lixiviant obtained by bacterial oxidation of the ferrous iron (concentration of $\mathrm{Fe}^{3+} 1300 \mathrm{mgL}^{-1}, \mathrm{pH} 2.14$ ). Biogenic lixiviant with ferric sulphate was then used in the leaching experiment at $80^{\circ} \mathrm{C}$. Maximal leaching degree was $78 \%$, and it was achieved after five minutes. Results of the leaching experiments show that the most efficient technology for copper recovery from the old flotation tailings of the Copper Mine Bor was leaching with biogenic lixiviant.
\end{abstract}

Keywords: copper extraction; flotation tailings; acid leaching; bioleaching; leaching with biogenic lixiviant.

\section{Introduction}

Flotation tailings is a mining waste generated during the production of mineral concentrate from the ore by application of froth flotation technology. The aim of the froth flotation is to concentrate sulphide minerals of the valuable metals such as copper, leaving gangue minerals in the tailings. The mineral concentrate, which contains on average 20-

*Corresponding author: Vesna Conić, vesna.conic@irmbor.co.rs 
$30 \%$ of copper, is further processed in smelters in order to produce pure copper. Approximately $99 \%$ (by weight) of the processed ore becomes flotation tailings [1]. The flotation tailings are a huge environmental problem, but in some cases, they can be a valuable secondary mineral resource [2]. The Copper Mine Bor, located in the eastern part of Serbia approximately $220 \mathrm{~km}$ from capital Belgrade, has been commissioned in 1903. The open-pit operations in the Copper Mine Bor started in 1912 and lasted until 1986. In order to make mineral concentrate, the ore was processed in the froth flotation facility. The residual tailings were deposited on the dump in the proximity of the plant. The old flotation tailings dump was in use from 1933 until 1987. The dump contains approximately $27 \times 10^{6} \mathrm{t}$ of flotation tailings, and it is separated on Field I and Field II [3]. Field $\mathrm{I}$ is older, it contains more copper dominantly in the form of oxide and sulphate minerals, while Field II contains less copper mostly as sulphide minerals [4-6]. It is estimated that old flotation tailings dump contains on average $0.18-0.2 \% \mathrm{Cu}, 0.3-0.35 \mathrm{~g} / \mathrm{t}$ $\mathrm{Au}$ and 2.17-2.5 g/t Ag [5, 7]. The Field I contains approximately 3.9 Mt of tailings with an average content of copper approximately $0.2 \%$; in deeper sections of the Field I (between 10 and $20 \mathrm{~m}$ of depth) up to $0.43 \%$ of copper was detected [5]. The ratio between copper oxide and sulphide minerals in the Field I is, depending of the sample, 1.8-1.5:1, indicating oxidation of copper sulphides to oxides and sulphates in the dump during years $[6,7]$. The average content of copper in Field II is approx. $0.1 \%$ with the content of copper sulphide minerals nearly four times higher than the content of oxide minerals [7]. The acid leaching of copper from old flotation tailings was investigated by Antonijević et al. [4] and Stevanović et al. [5]. Antonijević et al. [4] identified optimal conditions for acid leaching of the old flotation tailings. The influence of the sulphuric acid concentration was examined in the range of concentrations from $0.001 \mathrm{M}$ to $9 \mathrm{M}$. The authors identified $0.1 \mathrm{M} \mathrm{H}_{2} \mathrm{SO}_{4}$ as the optimal concentration for acid leaching. The effect of pulp density was tested at $20 \%, 25 \%, 33 \%$, and $50 \%$. The highest leaching degree of copper was detected at a pulp density of $33 \%$. The effect of the stirring speed was examined at 300 , 600 , and $900 \mathrm{rpm}$. Increase of stirring speed decreased time required to reach maximal leaching degree of copper from $30 \mathrm{~min}$ at $300 \mathrm{rpm}$ to $10 \mathrm{~min}$ at $900 \mathrm{rpm}$. The authors reported a maximal copper recovery of $60 \%$ after leaching with $0.1 \mathrm{M}$ sulphuric acid. Stevanović et al. [5] tested copper recovery from flotation tailings samples collected at different depths of the dump. The authors reported a variation of copper concentration with depth. At the surface of the dump concentration of copper was very low $-0.026 \%$, and it increased with the increase of depth: at $5 \mathrm{~m}$ it was $0.25 \%$, at $10 \mathrm{~m} 0.42 \%$, and at 20 $\mathrm{m} 0.43 \%$. The authors reported the highest copper extraction of more than $80 \%$ after acid leaching of samples collected from depths of $5 \mathrm{~m}$ and $10 \mathrm{~m}$. The leaching degree of copper was lowest after acid leaching of samples from $20 \mathrm{~m}$, indicating a higher proportion of copper sulphide minerals at this depth. The highest leaching degree of copper for $20 \mathrm{~m}$ samples was achieved after leaching with $0.01 \mathrm{M} \mathrm{H}_{2} \mathrm{SO}_{4}$ and $3 \% \mathrm{H}_{2} \mathrm{O}_{2}$, and it was approximately $48 \%$. Stanković et al. [6] examined bioleaching in shaken flasks of the old flotation tailings samples collected from depths of 10, 15 and $20 \mathrm{~m}$ of the Field I. The copper extraction for $10 \mathrm{~m}$ sample reached $98 \%$, for $15 \mathrm{~m}$ sample it was $68 \%$ and for 20 $\mathrm{m}$ sample $73 \%$. The X-ray diffraction analysis revealed that the most abundant copper mineral in the $10 \mathrm{~m}$ sample was langite: a copper sulphate mineral formed after precipitation of $\mathrm{CuSO}_{4}$, which has accumulated after oxidation of copper minerals in the upper sections of the dump. The content of langite decreased with depth, and the content 
of pyrite increased. The authors concluded that the old flotation tailings dump is vertically divided into three zones: oxidized zone (0-5) where copper sulphide minerals were almost completely oxidized, the zone of precipitation $(0-15 \mathrm{~m})$ where precipitation of copper sulphates occurred, and unoxidized zone $(15-30 \mathrm{~m})$ where oxidation rate of sulphide minerals was the lowest, and hence the concentration of sulphide minerals was the highest. Recently Han et al. [8] investigated leaching of copper from the old flotation tailings of Copper mine Bor under elevated pressure and temperature in the autoclave. The authors reported $98 \%$ leaching degree of copper under the following conditions: concentration of $\mathrm{H}_{2} \mathrm{SO}_{4} 0.5 \mathrm{M}$, pressure $2 \mathrm{MPa}$, temperature $180{ }^{\circ} \mathrm{C}$, leaching time 60 min, and concentration of solid phase $400 \mathrm{gL}^{-1}$.

Muravyov and Fomchenko [9] investigated leaching of copper, zinc, and gold from old flotation tailings from Russia, which contained $0.26 \% \mathrm{Cu}, 0.22 \% \mathrm{Zn}$, and $0.67 \mathrm{~g} / \mathrm{t}$ of $\mathrm{Au}$. They proposed three step leaching procedure: leaching with sulphuric acid for recovery of metals from oxide minerals, leaching with microbiologically produced lixiviant containing $30 \mathrm{gL}^{-1}$ of ferric iron for extraction of metals from sulfide minerals, and biooxidation of pyrite by acidophilic bacteria in order to liberate gold for extraction by cyanidation. The authors reported copper, zinc and gold recoveries of $79 \%, 96 \%$, and $96 \%$, respectively

This research aimed to test different approaches for copper recovery from old flotation tailings samples by comparing acid leaching in chemical reactor, bioleaching in a bioreactor, and chemical leaching with lixiviant produced by bacterial oxidation of ferrous iron.

\section{Materials and methods}

\section{Collecting samples}

A total of 40 samples was collected from depths of $5 \mathrm{~m}$ and $10 \mathrm{~m}$ at 20 locations from Field I of the Old flotation tailings dump and put in plastic bags, each having a mass of 50-60 kg. At the laboratory, subsamples were taken from each bag by coning and quartering method. Subsamples were mixed in order to make one composite sample.

\section{Methods}

For chemical analysis of the solid sample, $10 \mathrm{~g}$ of the composite flotation tailings sample was dissolved in aqua regia. After the dissolution of a solid sample, the concentration of $\mathrm{Cu}, \mathrm{Zn}, \mathrm{Fe}, \mathrm{Ag}$, and $\mathrm{Au}$ was determined by atomic absorption spectrophotometer Perkin Elmer Analyst 300 (Norwalk, USA). The concentration of Fe and $\mathrm{Cu}$ in the leach solution was also determined by atomic absorption spectrophotometry.

Mineralogical characterization of the tailings was performed by optical microscopy and XRD (X-Ray Diffraction) methods. A polarizing microscope Carl-Zeiss, model "JENAPOL-U" (Jena, Germany) equipped with 10×, 20×, 50×, 100× (oil immersion) objectives and a system for photomicrography ("Axiocam 105 colour" camera and "Carl Zeiss AxioVision SE64 Rel. 4.9.1." software package with „Multiphase” module, Carl Zeiss, Germany) was used for morphological investigations in reflected light. X-ray diffraction (XRD) patterns were obtained by using a Philips PW-1710 automated diffractometer (Philips, Netherlands) equipped with a $\mathrm{Cu}$ tube operated at 40 $\mathrm{kV}$ and $30 \mathrm{~mA}$. The instrument was equipped with a diffracted beam curved graphite 
monochromator and Xe-filled proportional counter. Diffraction data were collected in the $2 \theta$ Bragg angle range of $4-65^{\circ}$, counting for $1 \mathrm{~s}$.

Particle size distribution was determined by "Malvern Hydro 2000 MU” laser particle sizer.

Composition of the bacterial consortium for bioleaching

The bacterial consortium for bioleaching consisted of moderately thermophilic acidophilic bacteria: Leptospirillum feriphilum (autotrophic iron-oxidizing bacteria), Sulfobacillus sp. (mixotrophic bacteria), Acidithiobacillus caldus (sulfur-oxidizing acidophilic bacteria) and Ferroplasma sp. (iron-oxidizing heterotrophic acidophilic bacteria). The consortium was obtained from the mining company Mintek (Republic of South Africa). The composition of the bacterial consortium was determined and reported by Mintek. Bacterial culture was maintained in an incubator at a temperature of $45^{\circ} \mathrm{C}$. During adaptation and bioleaching, bacteria were cultivated in the diluted basal salts solution with the addition of flotation tailings as a source of energy. Composition of 50x concentrated basal salts solution was $\left(\mathrm{gL}^{-1}\right):\left(\mathrm{NH}_{4}\right)_{2} \mathrm{SO}_{4}-22.5 ; \mathrm{Na}_{2} \mathrm{SO}_{4} \times 10 \mathrm{H}_{2} \mathrm{O}-7.5$; $\mathrm{KCl}-2.5 ; \mathrm{MgSO}_{4} \times 7 \mathrm{H}_{2} \mathrm{O}-25 ; \mathrm{KH}_{2} \mathrm{PO}_{4}-2.5 ; \mathrm{Ca}\left(\mathrm{NO}_{3}\right)_{2} \times 4 \mathrm{H}_{2} \mathrm{O}-0.7$

\section{Experimental}

\section{Acid leaching experiments}

Acid leaching experiments were performed in a $2 \mathrm{~L}$ glass reactor equipped with a stirrer, thermometer, and funnel for the addition of the sample. Heating control of the reactor was provided by a heating mantle (Electrothermal, Staffordshire, UK). A total volume of the leaching solution was $1.2 \mathrm{~L}$. The experimental conditions for acid leaching were set according to [4]: volume of the solution for leaching $1.2 \mathrm{~L}$, the concentration of $\mathrm{H}_{2} \mathrm{SO}_{4} 0.1 \mathrm{M}$, pH 1, stirring speed $300 \mathrm{rpm}$, pulp density $30 \%$, temperature $80{ }^{\circ} \mathrm{C}$, leaching time $120 \mathrm{~min}$. The sample of the flotation tailings was added after the temperature of the solution reached $80{ }^{\circ} \mathrm{C}$.

\section{Adaptation of bacterial consortium for bioleaching of the old flotation tailings}

The bacterial consortium was adapted for more efficient growth on flotation tailings as substrate. The first adaptation stage was conducted in $250 \mathrm{~mL}$ Erlenmeyer flask with $3 \%$ pulp density: in $87 \mathrm{~mL}$ of the basal salts solution $\mathrm{pH} \mathrm{2,3} \mathrm{g}$ of flotation tailings, and $10 \mathrm{~mL}$ of bacterial culture was added. Flasks were put on an incubated orbital shaker (Heidolph, Germany), the rotation speed was $200 \mathrm{rpm}$, and the temperature was kept at $45{ }^{\circ} \mathrm{C}$. When the redox potential of the solution reached a constant value of $+600 \mathrm{mV}$, bacterial culture was collected for the next adaptation step. The duration of the first adaptation experiment was 15 days. The second adaptation step was conducted in $2 \mathrm{~L}$ laboratory bioreactor with 5\% pulp density: $200 \mathrm{~mL}$ of the bacterial culture from previous adaptation step and $100 \mathrm{~g}$ of flotation tailings was added into $1.7 \mathrm{~L}$ of basal salts solution. The temperature was $45^{\circ} \mathrm{C}$, stirring speed $250 \mathrm{rpm}$, airflow $0.5 \mathrm{~L} / \mathrm{min}, \mathrm{CO}_{2}$ flow 20 $\mathrm{mL} / \mathrm{min}$. After seven days of the experiment, the redox potential of the solution reached $+685 \mathrm{mV}$, and bacterial culture was collected for the final adaptation step. The conditions during the third adaptation step were the same as previous; the only difference was pulp density: the pulp density was increased to $10 \%$. The redox potential of the solution reached the final value of $+705 \mathrm{mV}$ after seven days. 
Bioleaching of the old flotation tailings

Bioleaching of the flotation tailings was conducted at $10 \%$ pulp density in $2 \mathrm{~L}$ bioreactor. Operating conditions were: temperature $45^{\circ} \mathrm{C}$, stirring speed $250 \mathrm{rpm}$, airflow $0.5 \mathrm{~L} / \mathrm{min}, \mathrm{CO}_{2}$ flow $20 \mathrm{~mL} / \mathrm{min}$. The bioreactor was inoculated with $200 \mathrm{~mL}$ of bacterial culture from the third adaptation step.

\section{Leaching with a biogenic lixiviant}

One liter of the solution containing $100 \mathrm{mM}$ ferrous sulfate pentahydrate and basal salts $\mathrm{pH}=2$ was inoculated with $100 \mathrm{~mL}$ of the bacterial consortium described in section 2.3. The flask was put on an orbital shaker and kept at $45^{\circ} \mathrm{C}$ for one week. After one week of incubation, deep red color and constant redox potential of the solution were established $(+620 \mathrm{mV}, \mathrm{pH}=2.14)$, indicating that the process of the iron oxidation was finished. The obtained solution was used as a lixiviant for the leaching experiment: 300 $\mathrm{g}$ of flotation tailings was added to the leaching solution, the temperature was set to 80 ${ }^{\circ} \mathrm{C}$, stirring speed to $300 \mathrm{rpm}$, duration of the experiment was 240 minutes. The sample of the flotation tailings was added after the temperature of the leaching solution reached $80{ }^{\circ} \mathrm{C}$.

\section{Results}

Chemical and mineralogical analysis of the flotation tailings

The results of the chemical analysis of the flotation tailings are presented in Table 1. The chemical analysis revealed that $50 \%$ of copper in the sample is in the form of oxide minerals.

Table 1. Results of the chemical analysis of the flotation tailings.

\begin{tabular}{lc}
\hline Chemical element & Concentration \\
\hline $\mathrm{Fe}$ & $7.78 \%$ \\
$\mathrm{~S}$ & $10.52 \%$ \\
$\mathrm{Al}$ & $6.58 \%$ \\
$\mathrm{Cu}$ total & $0.24 \%$ \\
$\mathrm{Cu}$ oxide & $0.12 \%$ \\
$\mathrm{Ag}$ & $3.00 \mathrm{~g} / \mathrm{t}$ \\
$\mathrm{Au}$ & $0.50 \mathrm{~g} / \mathrm{t}$ \\
$\mathrm{Zn}$ & $0.01 \%$ \\
$\mathrm{Cd}$ & $<0.001 \%$ \\
$\mathrm{Ni}$ & $0.004 \%$ \\
$\mathrm{As}$ & $0.022 \%$ \\
$\mathrm{~Pb}$ & $<0.030 \%$ \\
$\mathrm{Sb}$ & $<0.005 \%$ \\
$\mathrm{Mn}$ & $0.016 \%$ \\
$\mathrm{Mo}$ & $<0.001 \%$ \\
\hline
\end{tabular}

The results of the X-ray diffraction analysis of the flotation tailings are shown in Figure 1. The most abundant minerals in the sample were quartz, kaolinite, pyrite, and gypsum. Copper minerals were identified by microscopic examination of the sample. The most abundant copper sulphide minerals were covellite, chalcocite, and bornite, which were equally abundant, followed by chalcopyrite. The size of the chalcopyrite grain can 
reach $100 \mu \mathrm{m}$. Among copper oxide minerals, cuprite and $\mathrm{Cu}$-limonite were identified. Selected microscopic images are shown in Figures 2-5.

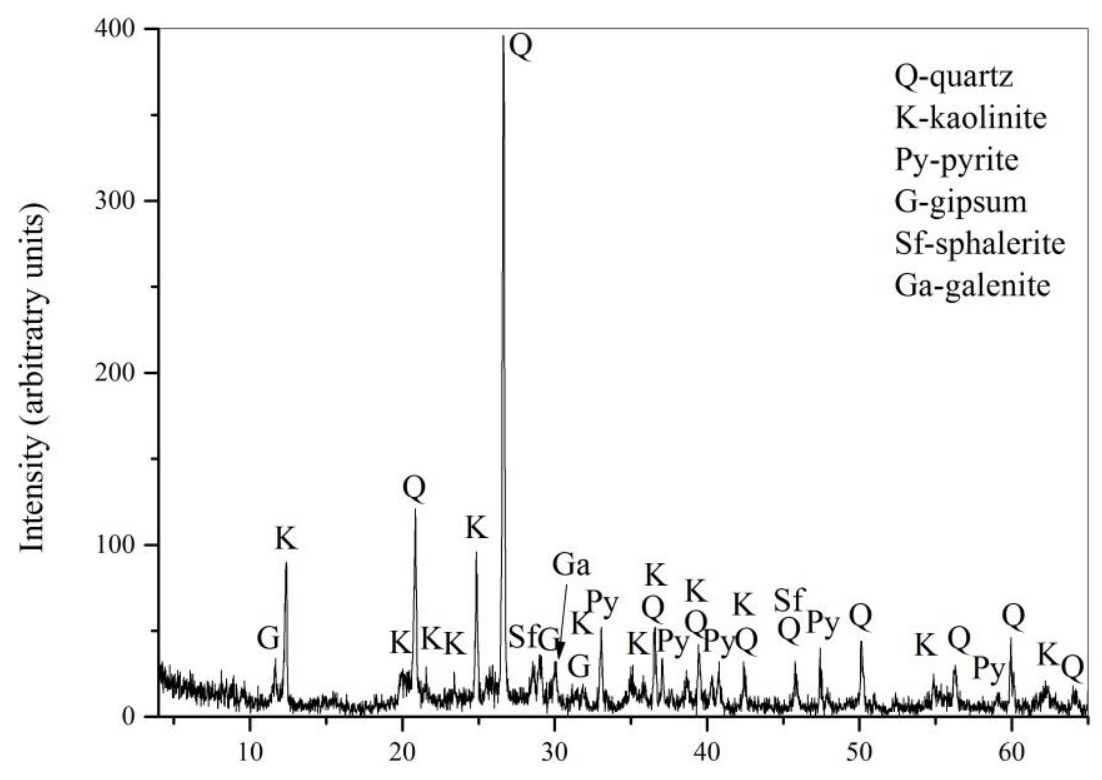

Fig. 1. Result of the X-ray diffraction analysis of the flotation tailings sample.

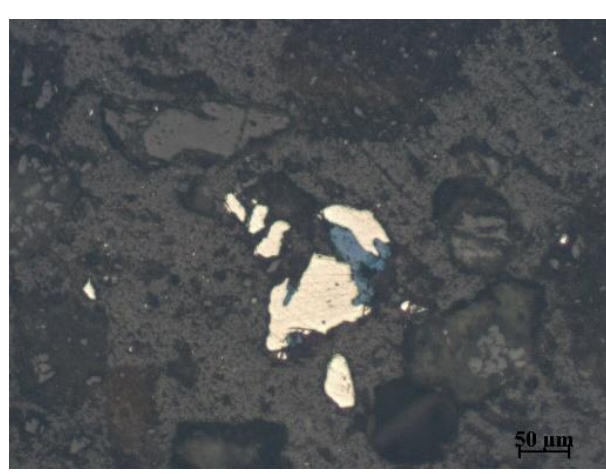

Fig. 2. Inclusions of covellite in pyrite.



Fig. 3. The free grain of chalcopyrite. 


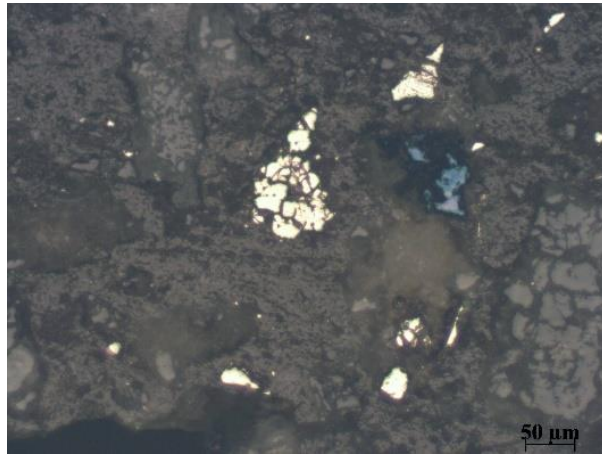

Fig. 4. The free grain of covellite.

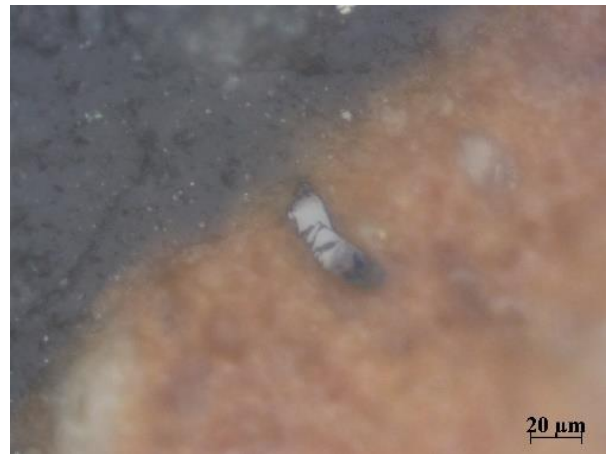

Fig. 5. Inclusion of cuprite in $(\mathrm{Cu})$ limonite.

Granulometric composition of the flotation tailings

The distribution of particle size by volume is presented in Table 2.

Table 2. Grain size distribution by volume in the flotation tailings sample.

\begin{tabular}{lcc}
\hline Size, $\mu \mathrm{m}$ & Volume, $\%$ & Volume below, $\%$ \\
\hline 500 & 0.77 & 99.09 \\
250 & 1.24 & 95.00 \\
150 & 1.60 & 90.92 \\
125 & 1.91 & 89.08 \\
106 & 2.13 & 87.17 \\
90 & 2.13 & 85.04 \\
75 & 2.69 & 82.43 \\
63 & 2.82 & 79.75 \\
53 & 2.81 & 76.93 \\
45 & 2.82 & 74.11 \\
38 & 3.09 & 71.03 \\
\hline
\end{tabular}


Results of the acid leaching experiment

Changes in the concentrations of iron and copper during acid leaching experiments and changes in the leaching degree of copper are presented in Figures 6 and 7.

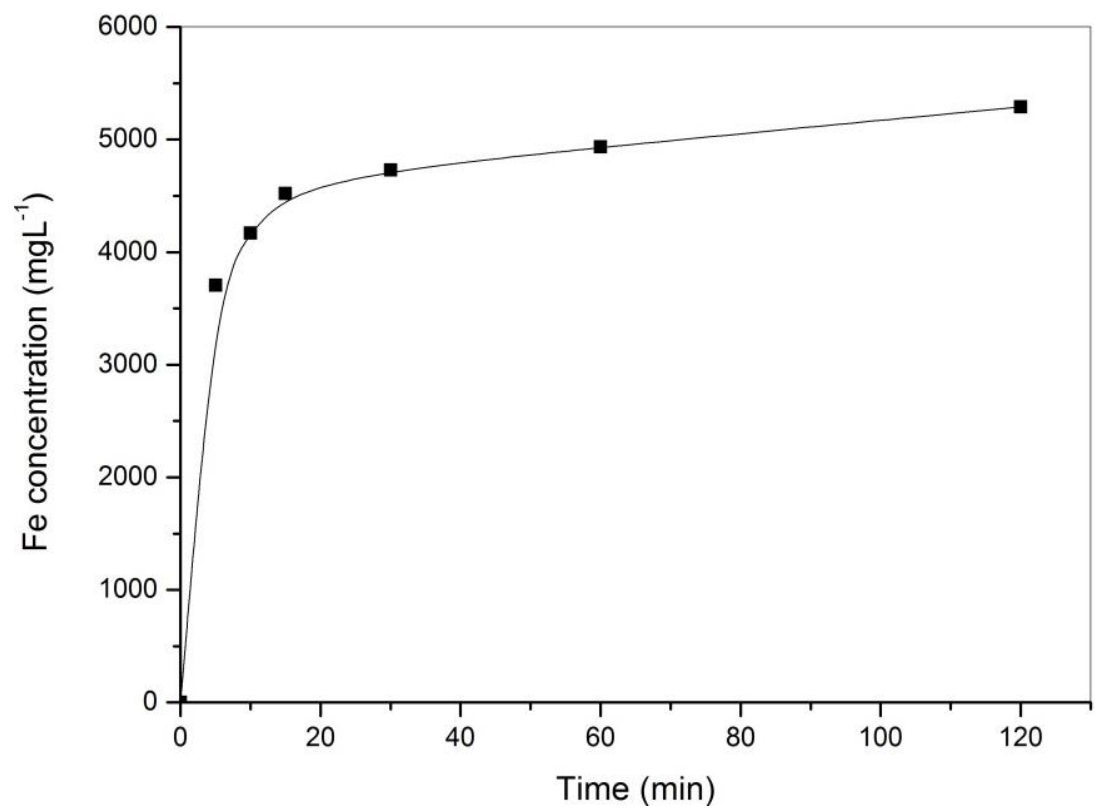

Fig. 6. Changes in the concentration of iron during the first acid leaching experiment

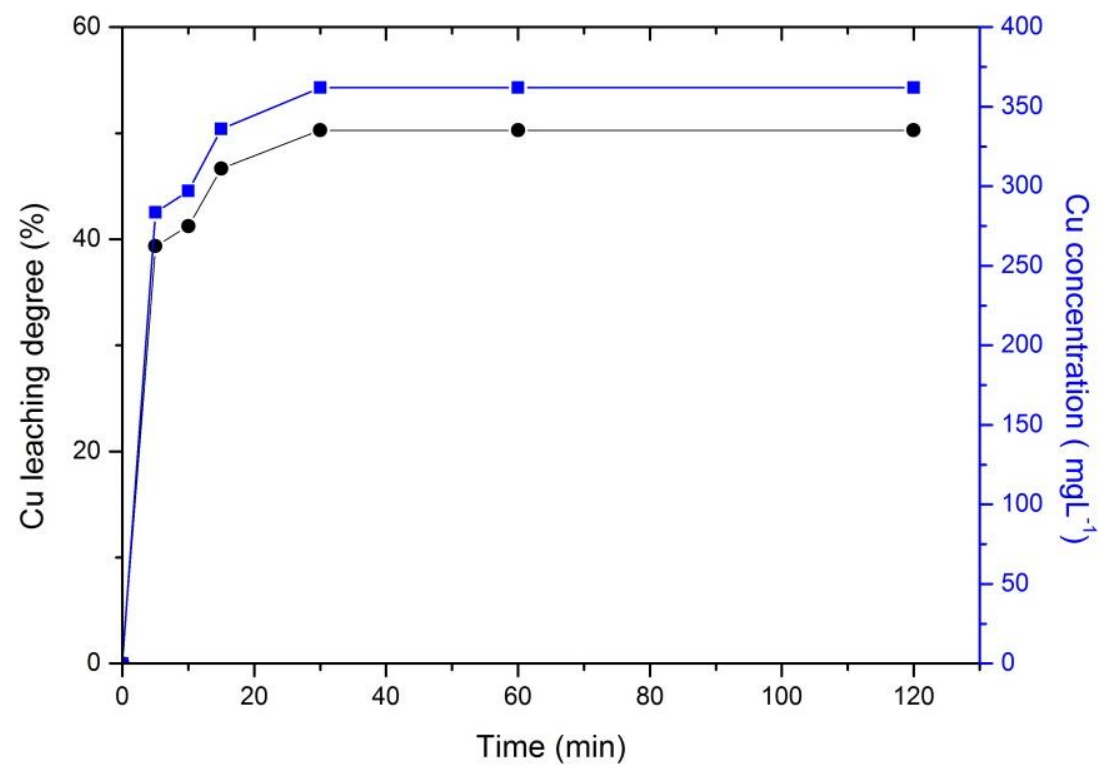

Fig. 7. Changes in the concentration of copper (square) and copper leaching degree (romb) during the first acid leaching experiment. 
Leaching of flotation tailings with $0.1 \mathrm{M}$ sulfuric acid leads to a dissolution of $50 \%$ of total copper. That is in accordance with the results of the chemical analysis: $50 \%$ of total copper in the tailings is in the form of the copper oxide minerals, which are acid soluble. The final concentration of copper in the pregnant leach solution was $362 \mathrm{mgL}^{-1}$. That concentration is not suitable for the application of solvent extraction/electrowinning technology (SW/EX) for extraction of pure copper, which requires copper concentrations of at least $1000 \mathrm{mgL}^{-1}$ [10], but that issue can be overcome by multi-step leaching.

Results of bioleaching of the flotation tailings

Results of the bioleaching of the flotation tailings are presented in Figures 8 and 9. After bioleaching of the flotation tailings, maximal copper extraction of $83.75 \%$ was achieved after 9 days of the experiment, and the concentration of copper in the pregnant leach solution was $402 \mathrm{mgL}^{-1}$. A slight decrease in copper concentration detected after the ninth day of the experiment might be the consequence of the ferric iron precipitation.

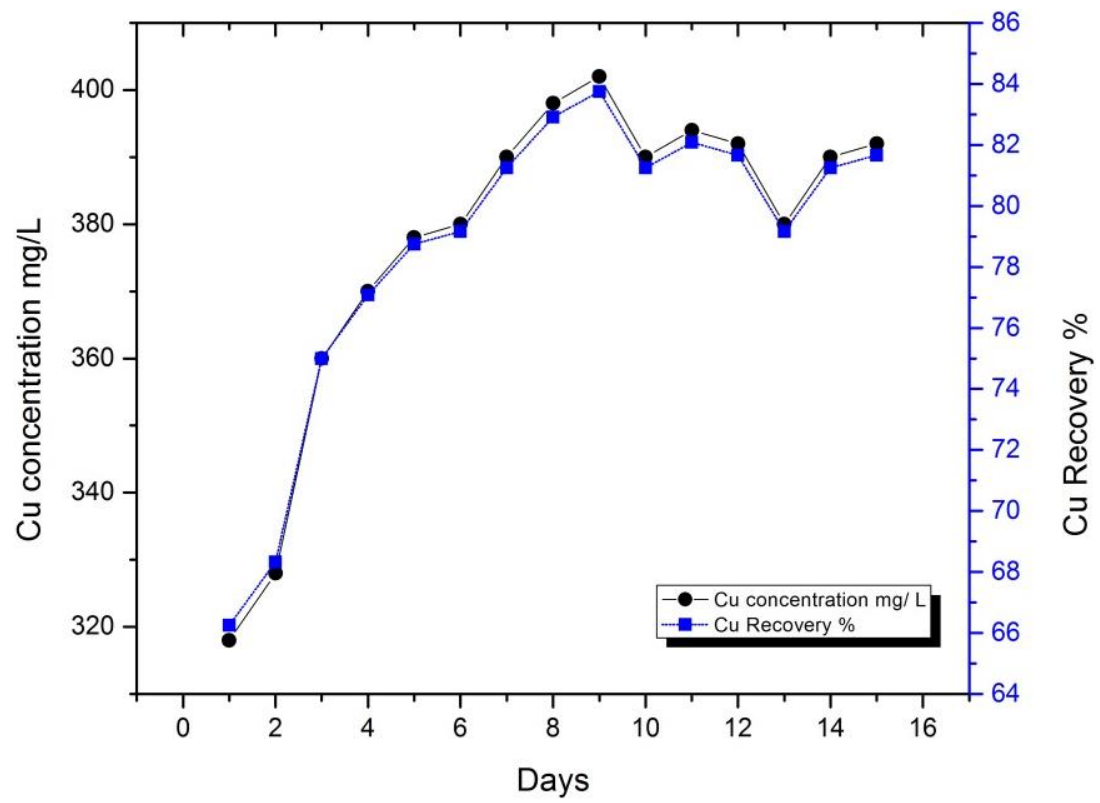

Fig. 8. Changes in the concentration of copper (circle) and copper leaching degree (square) during flotation tailings bioleaching. 


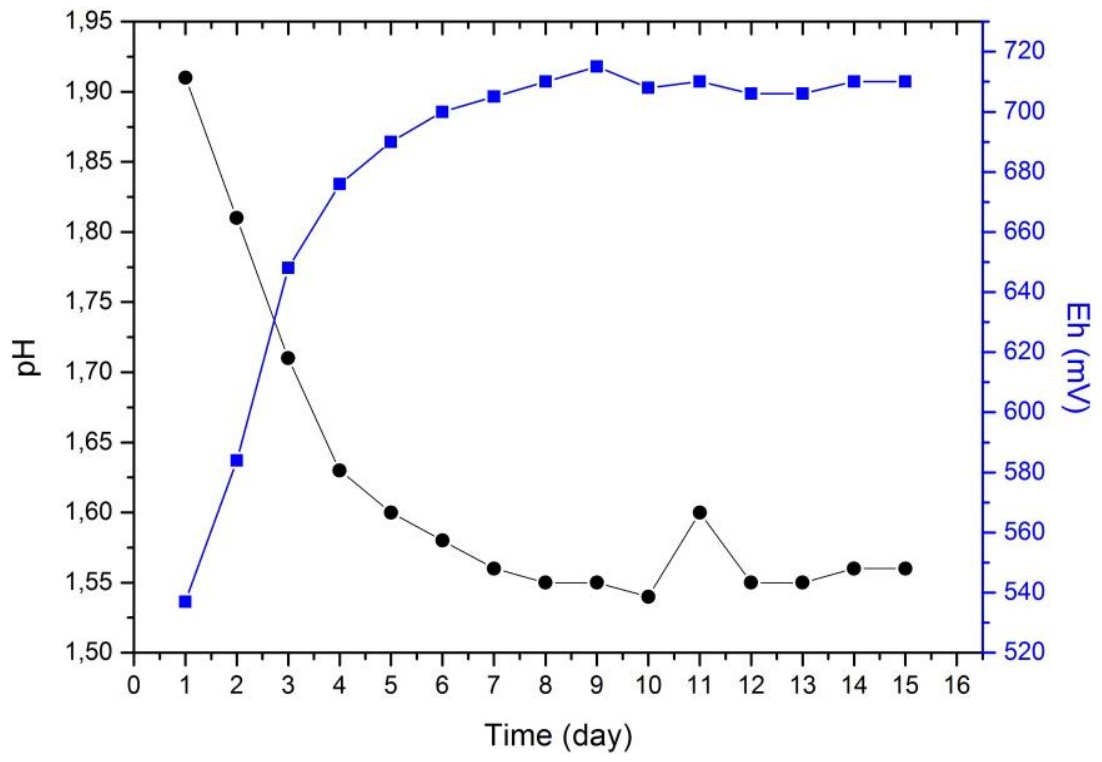

Fig. 9. Changes in $\mathrm{pH}$ (romb) and redox potential of the solution (square) during bioleaching.

Results of the leaching of flotation tailings with a biogenic lixiviant

Results of the flotation tailings bioleaching with biogenic lixiviant are presented in Figures 10, 11, and 12.

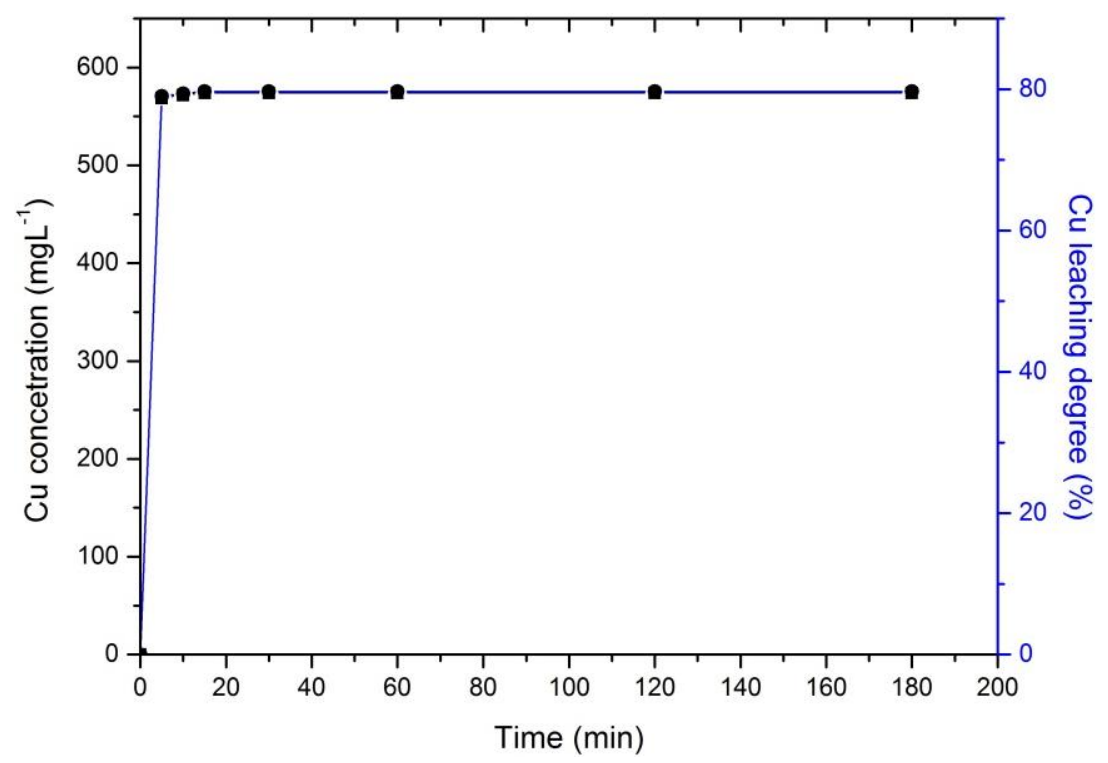

Fig. 10. Changes in copper concentration (square) and copper leaching degree (circle) during flotation tailings leaching with biogenic lixiviant. 


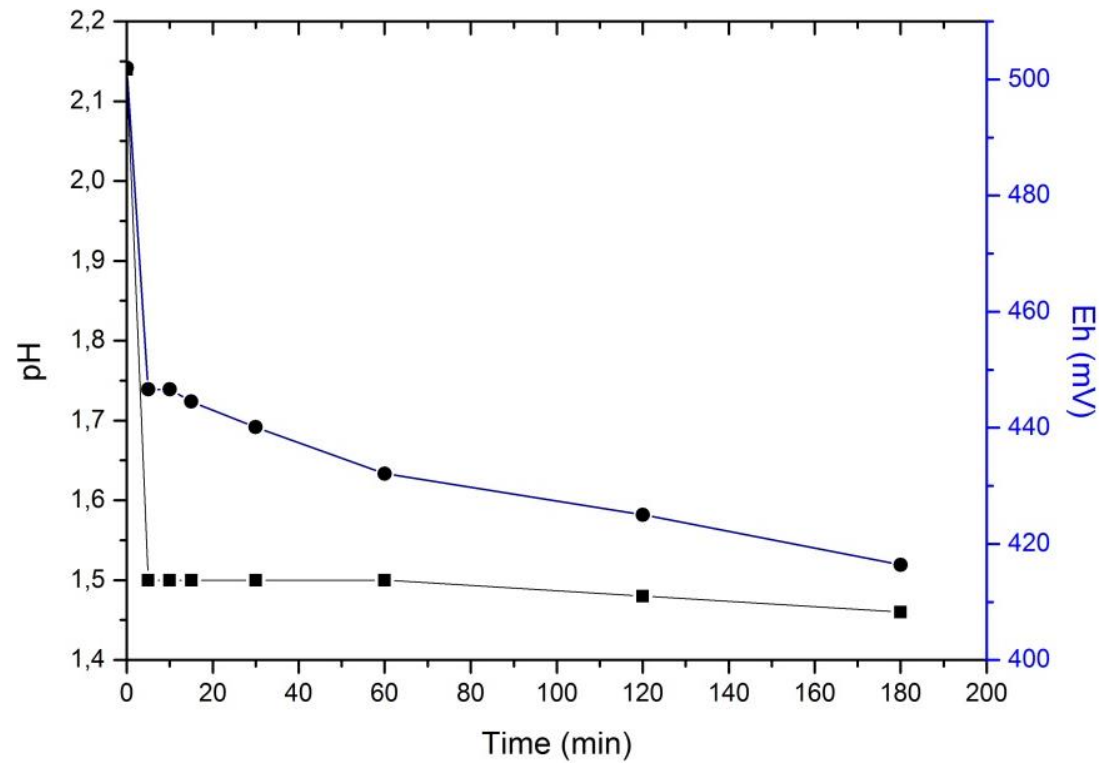

Fig. 11. Changes in pH (square) and redox potential (circle) of the solution during leaching with biogenic lixiviant.



Fig. 12. Changes in ferric iron concentration during flotation tailings leaching with biogenic lixiviant. 
The idea behind the third leaching experiment was to make acidic solution rich in ferric iron by bacterial oxidation of ferrous sulphate. That biogenic lixiviant was then used to leach copper from flotation tailings at $80{ }^{\circ} \mathrm{C}$ and pulp density of $30 \%[9,11]$. It was a chemical reaction without the help of bacteria that can not survive that temperature. Maximal leaching degree of copper $(79 \%)$ was achieved after five minutes of the leaching; the copper concentration in the PLS was $568.8 \mathrm{mgL}^{-1}$. At the same time, the $\mathrm{pH}$ of the leach solution dropped from 2.14 to 1.50 , and redox potential dropped from +520 $\mathrm{mV}$ to $+446.6 \mathrm{mV}$. Chemical reactions of copper sulfide minerals bornite, covellite, chalcocite and chalcopyrite oxidation by ferric iron are presented by equations $1-4$. A decrease in the ferric iron concentration could also be a consequence of the jarosite formation [12]. During oxidation of copper sulfide minerals, $\mathrm{Fe}^{3+}$ was reduced to $\mathrm{Fe}^{2+}$. Redox potential of the leaching solution depends on $\mathrm{Fe}^{2+} / \mathrm{Fe}^{3+}$ ratio $[13,14]$, higher positive redox potential means a higher concentration of $\mathrm{Fe}^{3+}$ ions over $\mathrm{Fe}^{2+}$ ions. As a result of the iron reduction, the concentration of $\mathrm{Fe}^{3+}$ decreased and consequently, the redox potential of the solution also decreased (Figures 11 and 12).

$$
\begin{aligned}
& \mathrm{Cu}_{5} \mathrm{FeS}_{4}+2 \mathrm{Fe}_{2}\left(\mathrm{SO}_{4}\right)_{3} \rightarrow 2 \mathrm{CuS}+\mathrm{CuFeS}+2 \mathrm{CuSO}_{4}+4 \mathrm{FeSO}_{4} \\
& \mathrm{Cu}_{2} \mathrm{~S}+2 \mathrm{Fe}_{2}\left(\mathrm{SO}_{4}\right)_{3} \rightarrow 2 \mathrm{CuSO}_{4}+4 \mathrm{FeSO}_{4}+\mathrm{S} \\
& \mathrm{CuS}+\mathrm{Fe}_{2}\left(\mathrm{SO}_{4}\right)_{3} \rightarrow \mathrm{CuSO}_{4}+2 \mathrm{FeSO}_{4}+\mathrm{S} \\
& \mathrm{CuFeS}+2 \mathrm{Fe}_{2}\left(\mathrm{SO}_{4}\right)_{3} \rightarrow \mathrm{CuSO}_{4}+2 \mathrm{~S}+5 \mathrm{FeSO}_{4}
\end{aligned}
$$

The oxidation of the pyrite is an acid generating reaction (5), which explains the drop in the $\mathrm{pH}$ value of the leach solution since pyrite is much more abundant in the flotation tailings in comparison to copper sulphide minerals:

$$
\mathrm{FeS}_{2}+7 \mathrm{Fe}_{2}\left(\mathrm{SO}_{4}\right)_{3}+8 \mathrm{H}_{2} \mathrm{O} \rightarrow 15 \mathrm{FeSO}_{4}+8 \mathrm{H}_{2} \mathrm{SO}_{4}
$$

\section{Discussion}

Leaching with biogenic lixiviant has obvious advantages over acid leaching and conventional bioleaching. The maximal copper extraction during bioleaching was achieved after 9 days and it was $83.75 \%$, on the other hand, maximal copper recovery during bioleaching with biogenic lixiviant was achieved after only 5 minutes and it was approximately $79 \%$. Pulp density has a high impact on bioleaching efficiency, many experiments confirmed that the efficiency of the bioleaching significantly decreases by increasing pulp density over $15 \%[15,16]$. The explanation of this phenomenon is a damage of the bacterial cells caused by friction with mineral raw material and accumulation of toxic chemical elements in the solution [17]. Successful adaptation of bacterial culture to pulp density of $20 \%$ was achieved in laboratory conditions, but the process lasted for two years [18]. Acidophilic bacteria can be relatively easily adapted to efficiently leach copper at $10 \%$ pulp density $[19,20]$. Commercial bioleaching operations in stirred tanks like BioCOP ${ }^{\mathrm{TM}}$ operate at $12 \%$ pulp density [21]. Lower pulp densities mean lower concentrations of copper in pregnant leach solution, meaning that in order to 
successfully recover copper additional step of copper concentration after bioleaching by ion-exchange or some other technology might be required. Also, at lower pulp densities, smaller amounts of mineral raw material can be processed in the one leaching cycle. Leaching with biogenic lixiviant is a chemical process allowing much higher pulp densities in the leaching solution (in this experiment it was 30\%), resulting in better processing capacity. Biogenic lixiviant can be obtained by microbiological oxidation of mining waste rich in pyrite. Such waste is abundant in the Bor mining area, and pyriterich mining waste is located in the proximity of the old flotation tailings dump. Pyrite oxidation is an exothermic reaction [22], the temperature of $80^{\circ} \mathrm{C}$ can be maintained in the bioreactor by oxidation of pyrite with an extremely thermophilic acidophilic ironoxidizing area which thrives in the environments with temperatures ranging from 70 to $90{ }^{\circ} \mathrm{C}$ [23]. Concentrations of copper over $1000 \mathrm{mgL}^{-1}$ in PLS, which are suitable for copper extraction by SX/EW technology, can be achieved by multi-step leaching in a series of chemical reactors.

\section{Conclusion}

Leaching with biogenic lixiviant is a promising and innovative approach for the recovery of copper from old flotation tailings of the Copper mine Bor. Bioleaching operations in two steps, were a production of biogenic lixiviant is separated from the leaching process, are not yet applied on a commercial scale. In this case, that approach is superior in comparison to other leaching technologies that were applied in this research for copper extraction from old flotation tailings. The yield of copper is significantly higher in comparison to acid leaching. Advantages over bioleaching are shorter leaching time and higher pulp density, allowing a higher amount of tailings to be processed in the one leaching cycle. Lower energy consumption and, consequently, lower operational expenses are advantages in comparison to high pressure leaching in the autoclave. Further research will focus on the optimization of the technology for copper leaching from flotation tailings by application of biogenic lixiviant in order to increase copper recovery.

\section{Acknowledgments}

The authors are grateful to the Ministry of Education, Science and Technological Development of the Republic of Serbia for the financial support (contracts 451-0368/2020-14/200023 and 451-03-68/2020-14/200052) of this investigation.

\section{References}

[1] B. Dold: Rev Environ Sci Biotechnol, 7 (2008) 275-285.

[2] D.H.R. Morin, P. d'Hugues, Biomining, first ed., Springer-Verlag, BerlinHeidelberg, 2007, 35-55.

[3] G. Bogdanović, M. Trumić, M. Trumić, D.V. Antić: Recycling and Sustainable Development, 4 (2011) 37-43. (In Serbian).

[4] M.M. Antonijević, M.D. Dimitirijević, Z.O. Stevanović, S.M. Serbula, G.D. Bogdanović: J Hazard Mater, 158 (2008) 23-34.

[5] Z. Stevanović, M. Antonijević, G. Bogdanović, M. Bugarin, V. Trujić, R. Marković, D. Nedeljković: Carpath J Earth Env, 8 (2013) 29-38.

[6] S. Stanković, I. Morić, A. Pavić, S. Vojnović, B. Vasiljević, V. Cvetković: J Serb Chem Soc 80 (2015) 391-405. 
[7] V. Stanković, V. Milošević, D. Milićević, M. Gorgievski, G. Bogdanović: Chem Ind Chem Eng Q, 24 (2018) 333-344.

[8] B. Han, B. Altansukh, H. Kazutoshi, Z. Stevanović, R. Jonović, Lj. Avramović, D. Urošević, Y. Takasaki, N. Masuda, D. Ishiyama, A. Shibayama: J Hazard Mater, 352 (2018) 192-203.

[9] M. Muravyov, N. Fomchenko: Miner Eng, 122 (2018) 267-276.

[10] Z. Stevanović, M. Antonijević, R. Jonović, Lj. Avramović, R. Marković, M. Bugarin, V. Trujić: J Min Metall B, 45B (2009) 45-57.

[11] N.V. Fomchenko, M.I. Muravyov, T.F. Kondrat'eva: Hydrometallurgy, 101 (2010) 28-34.

[12] H.R. Watling: Hydrometallurgy, 84 (2006) 81-108.

[13] D.E. Rawlings, H. Tribusch, G.S. Hansford: Microbiology, 145 (1999) 5-13.

[14] D. Bevilaqua, H. Lahti-Tomimila, O. Garcia, J. Puhakka, O.H. Tuovinen: Int J Miner Process, 132 (2014) 1-7.

[15] D.E. Rawlings: Microb Cell Fact, 4 (2005) 13.

[16] C. Astudillo, F. Acevedo: Hydrometallurgy, 92 (2008) 11-15.

[17] A. Mahmoud, P. Cezac, A.F.A. Hoadley, F. Contamine, P. d'Hugues: Int Biodeter Biodegr, 119 (2017) 118-146.

[18] Y. Wang, W. Zeng, G. Qiu, X. Chen, H. Zhou: Appl Environ Microbiol, 80 (2014) 741-750.

[19] L. Xia, X. Liu, J. Zeng, C. Yin, J. Gao, J. Liu, G. Qiu: Hydrometallurgy, 92 (2008) 95-101.

[20] S.Hedrich, A-G. Guezennec, M. Charron, A. Schippers, C. Joulian: Front Microbiol, 7 (2016) 2044.

[21] J.D. Batty, G.V. Rorke: Hydrometallurgy, 83 (2006) 83-89.

[22] H. Tributsch, J. Rojas-Chapana, Biomining, first ed., Springer-Verlag, BerlinHeidelberg, 2007, 263-280.

[23] D.B. Johnson, Physiology and Biochemistry of Extremophiles, first ed., ASM Press, Washington, DC, 2007, 257-270.

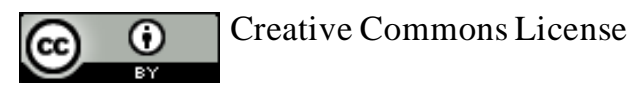

This work is licensed under a Creative Commons Attribution 4.0 International License. 